\title{
Transitioning to resilience and sustainability in urban communities
}

\author{
Marcus J. Collier ${ }^{\mathrm{a}, *}$, Zorica Nedović-Budić ${ }^{\mathrm{a}}$, Jeroen Aerts ${ }^{\mathrm{b}}$, Stuart Connop ${ }^{\mathrm{c}}$, Dermot Foley ${ }^{\mathrm{d}}$, Karen Foley ${ }^{\mathrm{e}}$, \\ Darryl Newport ${ }^{\mathrm{c}}$, Siobhán McQuaid ${ }^{\mathrm{f}}$, Aleksander Slaev ${ }^{\mathrm{g}}$, Peter Verburg ${ }^{\mathrm{b}}$ \\ ${ }^{a} U C D$ School of Geography, Planning and Environmental Policy, University College Dublin, Belfield, Dublin 4, Ireland \\ ${ }^{\mathrm{b}}$ Institute for Environmental Studies, IVM, Free University of Amsterdam, Netherlands \\ ${ }^{\mathrm{C}}$ Sustainability Research Unit, University of East London, 4-6 University Way, London E16 2RD, UK \\ ${ }^{\mathrm{d}}$ Dermot Foley Landscape Architects, Malapas Street, Blackpitts, Dublin 8, Ireland \\ e UCD School of Architecture and Landscape, University College Dublin, Belfield, Dublin 4, Ireland \\ ${ }^{\mathrm{f}}$ European Business and Innovation Centre Network, Avenue de Tevueren 168, C-1150 Brussels, Belgium \\ ${ }^{\mathrm{g}}$ Faculty of Architecture, Varna Free University, 9007 Varna, Bulgaria
}

\section{A R T I C L E I N F O}

Article history:

Available online 23 April 2013

\section{Keywords:}

Urban resilience

Transition strategy

Sustainability

\begin{abstract}
A B S T R A C T
Adapting to the challenges of rapid urban growth and societal change will require mechanisms for efficient transitioning to an embedded resilience. This has become central to the exploration of methods for achieving truly sustainable urban growth. However, while transitioning and resilience are useful descriptors, they can be abstract or conflicting ideals and their meanings obscured by a lack of concrete examples, both being barriers to many planning objectives. In this paper, we hold a lens over key issues in transitioning to resilience in urban areas by outlining emerging challenges that may offer directions towards operationalising how cities might transition to a more resilient future, while ensuring that communities are at the center of the process. The emerging and challenging areas - geospatial ICT, green infrastructure planning, novel design using collaborative responses, climate planning, limiting urban sprawl and short-circuit economic approaches - are explored as viable facets for devising and sustaining urban transition strategies. We conclude with a discussion on the need for developing a synergistic approach in practice to facilitate transition.
\end{abstract}

(c) 2013 Elsevier Ltd. All rights reserved.

\section{Introduction}

There is now a plethora of interlocking discussions on resilience and resilience thinking. Resilience can have different nuances (Porter \& Davoudi, 2012). It can be used to describe a response to environmental disturbance or how habitats and ecosystems can re-organise spontaneously after a disturbance (Holling, 1973). It can be used to describe the vulnerability of a system to irreversible change (Adger, 2006). It can mean the capacity for adaptation within a system and, in relation to human systems, the ability to learn and adapt. The interaction between humans and ecosystems can have divergent effects within urban settings, since on the one hand there is a drive to live more sustainably while concurrently there is the drive to sustain communities and livelihoods. The notion of urban resilience is a relatively new concept and is still hotly debated (Ernstson et al., 2010). It has been defined as "the degree to which cities are able to tolerate alteration before reorganizing around a new set of structures and processes" (Alberti et al., 2003, p. 1170).

\footnotetext{
* Corresponding author. Tel.: +353 17162718.

E-mail address: Marcus.Collier@UCD.ie (M.J. Collier).
}

While there are numerous studies of resilience and urbanisation, little is known of the impact that participation by urban stakeholders may have on communities and environments or the effects that 'greener' environments may have on communities (Lee \& Maheswaran, 2010; Tzoulas et al., 2007). However, it may be possible to conceive of the varying dimensions of urban change and the core aim of provisioning for resilient systems. One conception of this is shown in Fig. 1, where we seek to illustrate some of the dimensions of resilience as they may apply in a challenging urban setting. Each of the 'sides' of the discussion features a key element in understanding pathways to finding solutions to challenges to urban resilience. For example, some of the underpinning barriers to urban resilience planning relate to historical and infrastructural development, geopolitical location and ecosystem processes such as vulnerability to flooding. In addition, some of social barriers include the capacity of a community to adapt and to influence adaptive processes, local planning policies, the degree of community capital and the relative size of an area within the larger entity. Finally, there are significant downward stressors, such as power asymmetries, a globalized economy and demographic change. Embedded within these and other issues is the notion of resilience. At the 'corners' or 'edges' of this conception, resilience and 


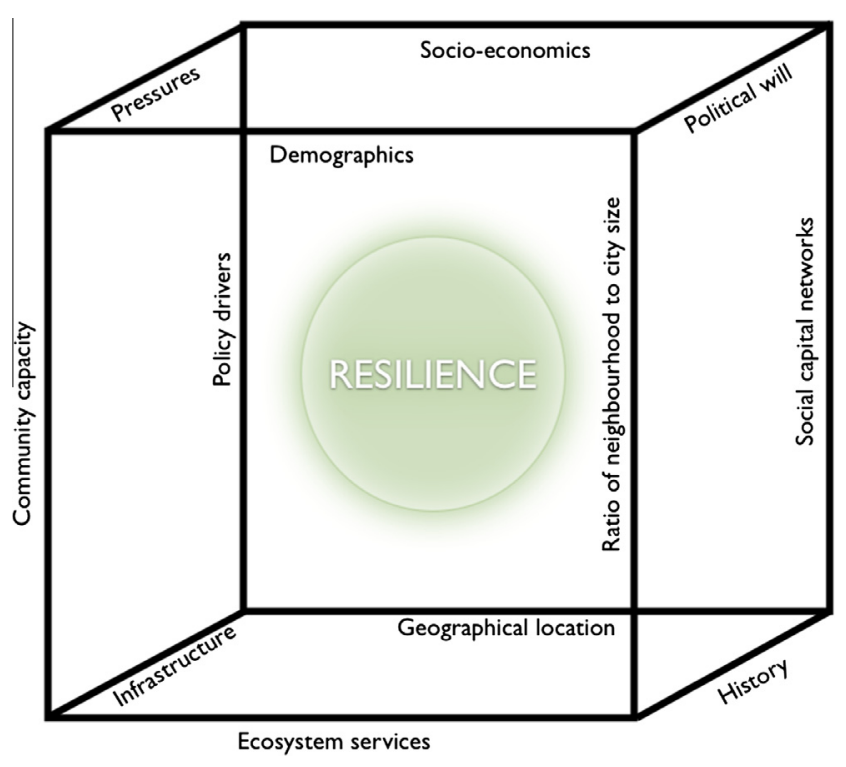

Fig. 1. A stylised conception of resilience in an urban setting.

sustainability planning requires a diverse range of disciplines and perspectives.

This paper identifies and explores several key questions that apply across urban and spatial planning. These questions emerged from preliminary research for designing a new multidisciplinary urban transition project, TURAS (Transitioning towards Urban Resilience and Sustainability). This project, which commenced in October 2011 (see www.turas-cities.eu), is a product of the coming-together of differing disciplines (e.g. spatial planning, landscape architecture, climate science, economics, sustainability science and ecology) motivated by the desire to see truly interconnected research manifested into demonstrable strategies for urban areas. Therefore, the aim of this paper is not to limit the discussions to several disciplinary arenas, nor is it to be reductive or prescriptive at the expense of other experiences, rather it is to propose that the journey towards a meaningful transition may begin when these arenas become embedded in urban planning and design policy. Thus this paper aims to draw attention to areas with a high potential for demonstrating effective and realistic transitioning policies.

\section{Resilience}

The emergence of resilience as a driver of urban policy has resulted in a turn towards a more integrated, multi-disciplinary and open planning system, one that views community stakeholders as central to the planning process and one that sees the planner as innovative, creative and holistic (Lawrence, 2004; Ling, Handley, \& Rodwell, 2007), working within a theoretical framework of multi-disciplinarity and multi-functionality (Ahern, 2011). Such an approach has been discussed and debated in the context of rural landscape planning and management (Naveh, 2000; Palang, Alumae, \& Mander, 2000). Resulting rural policies reflect this. There is now an emerging narrative at a European level for the promotion of multi-functionality in rural landscapes, which is seen as the best mechanism for sustaining rural livelihoods and nature conservation (Antrop, 2004; Berkel \& Verburg, 2012; Slee, 2007; Vos \& Meekes, 1999). Such debates are poorly developed in urban landscapes (Wilkinson, 2012b), though resilience as a planning theme has been given high priority and thus expectation. Resilience is an emergent property of a system and cannot be understood or predicted by explaining the parts (Berkes \& Turner, 2006). Resilience simultaneously absorbs change and provides the capacity for change. Therefore, complex systems (where human and ecological communities are inter-reliant) are self-organising at critical points of stability and cannot be viewed using linear thinking, nor fully or adequately planned for using a reductionist approach, such as zoning or regulation for example. Adger (2000, 2006) proposes that social resilience mirrors ecological resilience and may be central to achieving sustainable development programmes. Thus, the importance of utilising multiple perspectives in the analysis and management of complex systems as well as the recognition that local, non-expert knowledge has a high value in landscape management is evident. Folke, Hahn, Olsson, and Norberg (2005) explore the community side of this issue and they suggest that a form of environmental governance may be used to link local stakeholders and expert actors to generate resilience against uncertainty and unpredictability, and this has been used to envision resilience-based scenarios with respect to climate change (Gidley, Fien, Smith, Thomsen, \& Smith, 2009) and collaborative planning (Selman, 2004).

Recent debates on the difficulties of incorporating resilience policies into practice (e.g. Porter \& Davoudi, 2012) reveal that while deconstructing resilience offers insights and opportunities for multi-faceted approaches (Davoudi, 2012) this does not always offer insight into practical or operationalised implementation. Responding to these challenges requires building or stimulating social and ecological resilience (Wilkinson, 2012a). It will require solutions that also address existing socio-economic, cultural and historic urban development challenges, and this creates a very complex problem for planners and practitioners. Urban development, whether compact or dispersed, results from a variety of forces, some working on the individual and some on the systemic level. In many European cities, traditional planning has often focused on addressing, among many things, design responses to complex social challenges and damaged or depleted neighbourhoods (Kennedy, Pincetl, \& Bunje, 2011). This has resulted in specific design prescriptions that tackle the initial issue but cannot respond to changing social structures, improving environmental and cultural awareness or newer values of, and demands from, public spaces. These newer, complex demands include collaborative approaches to the conservation, restoration and augmentation of ecosystem services, such as biodiversity, flood control, waste management, air quality and carbon sequestration (Berkes \& Turner, 2006; Colding, 2007; Cook, Hall, \& Larson, 2012; Folke, Holling, \& Perrings, 1996). In addition, there is a growing awareness that the future of civil society is inextricably linked to maintaining and valuing ecosystem services in an attempt to retain ecological and social resilience (Alberti \& Marzluff, 2004; Hubacek \& Kronenberg, 2013; MA, 2005). Furthermore, health research is now showing the inter-relatedness between citizen health and quality of life and high quality environmental conditions and green spaces (Lee \& Maheswaran, 2010; Maas, Verheij, Groenewegen, de Vries, \& Spreeuwenberg, 2006).

Moving closer to ensuring resilient urban communities will require a long-term and integrated approach to city planning and development (Antrobus, 2011). This may involve significant and meaningful participation by all stakeholders, as has been discussed in relation to diverse urban issues such as recreation (Huang, 2010), sanitation (Lüthi, McConville, \& Kvarnström, 2009) and flooding (van de Meene, Brown, \& Farrelly, 2011), to name but a few. However, stakeholder engagement can yield outcomes that can be contested (Collier \& Scott, 2008), which is perhaps a natural property of human collaboration, so it is necessary for planners to drive the transition process using modern collaborative and holistic tools as well as achievable and demonstrable exemplars. So, how transition to a resilient urban society draws upon 
numerous factors and there are many culture- and site-specific parameters that may impede broad-spectrum prescriptions.

\section{Can Geospatial ICT (G-ICT) support infrastructure for resilience planning?}

The broad reliance on information and communication technologies (ICT) and provision of spatial data infrastructures (SDIs) in support of sustainable development are still in their infancy (Masser, 2005). The demand to plan for urban resilience presents additional infrastructural and technological requirements (Allenby and Fink, 2005), with long-standing issues of content, scale, method, access and interoperability remaining pertinent to Geospatial ICT (G-ICT). While the amount and diversity of data continue to proliferate, along with their increased accessibility, the information and procedures that satisfy the level of detail and contents needed for addressing urban resilience are sparse and unsystematic at best. By the end of the second decade of this millennium, many cities will have developed a geospatial database, most to be available on the Internet or a local intranet. Such databases tend to be populated with general information often derived from national census and offering some local data, but generally deprived of the pertinent and detailed datasets to support the sustainable urban development agenda. According to Nedovic-Budic, Feeney, Rajabifard, and Williamson (2004) and Nedović-Budić, Knaap, Budhathoki, and Cavrifá (2009) it is the local, integrated and purposedriven datasets that are essential building blocks of viable information infrastructures. These locally relevant datasets are more likely to provide direct utility in facilitating solutions to problems such as urban sprawl, depletion of resources and impact of climate change. Wang, Song, Hamilton, and Curwell (2007) agree that those integrated urban level datasets both enable e-planning and enhance the planning process.

Planning information is often integrated and often involves the use of data represented in various scales ranging from large (e.g., $1: 5000$ ) to small (e.g. 1:25,000) and with boundaries derived through institutional, administrative or analytical processes (e.g., planning jurisdictions, districts, census tracts, neighbourhoods, subdivisions, traffic analysis zones, blocks and land parcels) as well as those defined ecologically (e.g., critical areas, watersheds and drainage basins, 'airsheds', and habitats). In addition, there is a range of graphical, numerical and textual information from planning documents such as plans, ordinances and reports. These integrated and accessible datasets are the primary elements of G-ICT, and are the basis for the development of spatial data infrastructures in support of urban resilience and sustainability. At the European level the standardized provision, integration and shared access to geospatial databases is established through the Infrastructure for Spatial Information in Europe (INSPIRE) Directive (EC, 2007). Though still in its implementation phase, this development has been motivated by the need to harmonize data for environmental planning and management across the European Union, and clearly carries some relevance for urban sustainability and resilience, albeit at a somewhat generalized level.

However, the challenges of integrating data from various sources and ensuring their formatting and functional interoperability are many (Buccella, Cechich, \& Fillottrani, 2009). Metadata are, obviously, the first call of duty for an information infrastructure at any scale to secure understanding of the diverse datasets - their origin, contents, purpose, format, and access, among others. Development and agreement on data models and network service architecture is also needed, as exemplified by Plan4all project which proposes solutions for seven INSPIRE themes that are relevant for planning: land cover; land use; utility and government services; production and industrial facilities; agricultural and aquaculture facilities; areas management/restriction/regulation zones and reporting units; and natural risk zones (Salvemini, \& Iannucci, 2011). Preceding this effort is Hopkins' et al. (2005) provision of the conceptual schema for organising the planning data, actors, assets, actions, decision situations, plans and system architecture for implementation of Planning Markup Language.

The key and most common problem in the integration process remains heterogeneity (Hakimpour, 2003). The variety of terms used in planning across different European regions and countries presents a major challenge. Lacasta, Nogueras-Iso, Béjar, Muro-Medrano, and Zarazaga-Soria (2007) state that even though standards and specifications have been put in place to facilitate interoperability, important semantic differences still remain. They also highlight the barrier of multilinguality and the increasing number of official languages as a main barrier in the establishment of a European G-ICT infrastructure. To be effective, G-ICT should serve all aspects of the planning process and enable a variety of methods, including analysis, communication and visualisation (Förster \& Thierstein, 2012). The appraisal of alternative urban plans and actions involves analytical and systematic determination of all factors (Coutinho-Rodrigues, Simão, \& Antunes, 2011) and requires a broad range of analytical tools, techniques and models. Geographic information systems (GIS) technology, in particular, offers a wide range of analytic tools and methods such as feature, grid and network analyses, as well as change, impact and decision modeling (Nyerges \& Jankowski, 2009). These additional G-ICT functionalities also carry the potential to enhance the visualisation of planning issues and solutions. Interactive GIS-based scenario analysis tools, Geoweb tools and 3D visualizations can present spatial characteristics and help demonstrate consequences of environmental and urban change in a compelling manner (Sheppard, 2005).

Communication as a planning method has huge significance for pursuing the principle of collaboration needed to make progress toward resilience. G-ICT incorporates Web2.0 tools such as planning blogs, wikis, chat rooms, discussion forums, virtual communities, mailing lists which can be used to promote citizen participation in planning decision making and more active contributions to the planning process (Silva, 2010). The explosive growth of Geoweb has made GIS a powerful medium for the general public to visualize spatial phenomena, but perhaps, more importantly, to engage in constructive dialogs and interactions about social issues (Sui \& Goodchild, 2011). Planners may also use these bilateral dialogs for the dissemination of information to citizens. Web 2.0 technology has opened up the possibilities for interactive systems and volunteered geographic information (VGI) (Budhathoki, Bruce, \& Nedovic-Budic, 2008; Budhathoki, Nedovic-Budic, \& Bruce, 2010). The VGI phenomenon of using and contributing spatial information content via the Internet has opened up new possibilities for citizen involvement in the process of urban planning, decision-making and community action. While the majority of ongoing VGI practices are confined to mapping of geometric primitives (points, lines and areas) and adding photos or comments on top of an existing digital base, community and participatory uses are slowly emerging (e.g., citizen science, see Haklay, 2010).

Thus, when seeking to elicit, analyse, augment and/or distribute information a G-ICT approach may offer an accessible portal for communities of interest seeking to address urban stressors and thus may open a pathway to ensuring more inclusive planning and decision-making processes, something that resilience building will increasingly require (Adger et al., 2011; UNDP, 1997), and which may facilitate a more rapid response to urban communities. G-ICT has moved from standalone devices operated by institutions and experts to popular tools used by broad public and private audiences and society at large (Longley, Goodchold, Maguire, \& Rhind, 2010). G-ICT is considered essential for facilitating spatially- 
enabled e-governance (Nedovic-Budic, 2010). With G-ICT established as a collaborative platform, the following questions can now be pursued with an aim towards devising strategies for transitioning.

\section{Can public and private green infrastructure become mainstreamed?}

Urban green space policy is increasingly being used as a tool to enhance urban resilience and sustainability. Relying on assumptions of the intrinsic attributes of green infrastructure may, however, result in targets for supporting biodiversity and ecosystem services being missed (Simmons, Gardiner, Windhager, \& Tinsley, 2008). Augmenting the economic models, novel field-based research trials and landscape-scale case studies may consolidate an understanding of the potential of green infrastructure to contribute to sustainable urban communities (Gómez-Baggethun \& Barton, 2013). For example, building on the pioneering horticultural and economic drivers of green roof research (Dunnett \& Kingsbury, 2008) and incorporating and enhancing the green roof biodiversity expertise (Kadas, 2006) and existing research programmes (Connop, Gedge, Kadas, Potter, \& Newport, 2009), innovation in green roof technology (in combination with landscape-scale installation, monitoring and dissemination) may show that green infrastructure can be designed to maximise the biodiversity, ecosystem services and carbon storage value of green spaces, if designed towards specific goals (Simmons et al., 2008). Such demonstration would provide impetus for Europe-wide green roof planning guidance and green infrastructure restoration to move away from industrially standardized generic 'greenwash' towards reinstating an ecologically functioning urban landscape (Pickett et al., 2001). Next to green roofs, other ways of enhancing green infrastructure in the urban context should be considered such as the role of private domestic gardens (Cameron et al., 2012), and urban agriculture (Goddard, Dougill, \& Benton, 2010) and innovative urban landscape design (Connop, Lindsay, Freeman, \& Kadas, 2011 ) in conserving regionally important biodiversity and providing food security (SCBD, 2012). Green infrastructure can be optimized by combining new technologies, public and private initiatives in a coherent strategy.

To ensure appropriate dissemination and implementation of any new technology, research should take the form of Knowledge Transfer Partnerships with local authorities and SMEs and should concentrate on potential mechanisms for, and barriers to, widespread incorporation of urban green infrastructure and biomimicry, urban carbon sinks and biodiversity-rich green space. Direct involvement of these stakeholders would provide a platform for the synergy of economic, artistic and ecological perceptions of green infrastructure design and innovation with a view towards creating healthier urban environments (Hostetler, Allen, \& Meurk, 2011). Moreover, such collaboration could provide a foundation for the development of evaluation tools for sustainably financing green infrastructure through payment for ecosystem services (DEFRA, 2011) and thus climate resilience building, which Gidley et al. (2009) see as augmenting community stakeholder collaboration and participation. How such augmentation may be facilitated and operationalised is discussed next.

\section{Can collaborative processes facilitate creative design?}

Urban communities must be seen as the central stakeholders in transitioning objectives. Current trends in creative landscape design relate to process driven outcomes as opposed to rigid spatial sequence and composition. Urban designers are concerned with the process of movement, but this can include the recording and perception of space as a continuum and the process of change, through biological agents, human agents or combined systems. The challenge to designers now is to build a resilient quality into this process and to elicit engagement at levels that may be outside the comfort zone of many stakeholders. Vigar and Healey (2002) discuss how the term stakeholder has been useful for describing the various actors, human as well as non-human, participating in and affected by an environmental issue. They note that some stakeholders have more power and voice than others (for example within social classes) and this can lead to asymmetries in environmental and governance policies (Marafa, 2002). Transition policy, therefore, ought to be based on deliberative processes, be communicated clearly and be informed by significant inter-connection between stakeholders and facilitate participation by 'weaker' stakeholders. In the urban planning arena there can be an imbalance between those who take the view that scientific knowledge may out-weigh non-scientific, local knowledge (Burgess, Clark, \& Harrison, 2000; Collier \& Scott, 2009). The current emergence of community-led land-use projects (e.g. Porter \& Salvesen, 1995) owes much to both changing perception and physical process. Collaboration seeks to stimulate processes that are citizen conceived and driven, facilitated by wider stakeholders, and drawing on existing social capital networks with further collaboration from academic research, management practice and innovative design groups (Hostetler et al., 2011). Citizen-led planning entails a fundamental shift in the planning paradigm with the focus on facilitating communities in creating a concept for their future needs and wishes, while seeking to work with planning stakeholders on an egalitarian level. It is proactive, rather than reactive.

Urban communities, however, may conceive resilience in many ways. For example, some may see it as maintaining the status quo and others may view it as an opportunity to design for a new environment, with issues such as quality of life featuring prominently. Investigations of the relationship between urban living, health and green spaces has moved center stage in recent years. de Vries, Verheij, Groenewegen, and Spreeuwenberg (2003) demonstrated this inter-relationship, noting that there is a positive correlation between improved heath and green spaces among residents in socio-economically deprived neighbourhoods. European research (Groenewegen, van den Berg, de Vries, \& Verheij, 2006) mirrors that in North America (Twiss et al., 2003), prompted by observational discoveries (Kaplan \& Kaplan \& Kaplan, 1983; Ulrich, 1984). Some explore the notion that 'greening the city' may prolong life (Takano, Nakamura, \& Watanabe, 2003) but support data are poor, and Bell, Montarzino, and Travlou (2007) note that while green space mapping has been well covered by planning and socio-economic analyses, there has been little focus on health and welfare. However, it is clear that, while research is aimed at policy makers, it can be too vague for developing working prescriptions. Thus, we note the need for a transdisciplinary approach (Lawrence, 2004), and the creative and inclusive involvement by wider disciplines and stakeholders, with planners and practitioners as facilitators. This can mean becoming more open to actors that are outside traditional disciplines, and transdisciplinarity therefore de facto refers to inclusion of cultural knowing as well as other forms of knowledge (Fry, 2001). This move has been stimulated by the emergence of a need to react to sudden shocks in urban areas, and now is at the center of the response to global environmental changes, especially when it comes to the challenges that climate change may pose to certain urban areas. Recently, it has been observed that the drive towards 'greening' or building resilient cities may also stimulate social capital in urban communities (Colding \& Barthel, 2013; Guitart, Pickering, \& Byrne, 2012; Hunter \& Brown, 2012), thus pointing towards the various social and ecological benefits that can be derived when exploring collaborative processes. 


\section{Can we operationalise climate resilient city planning?}

The impact of natural hazards on global cities and economies is likely to increase in the future due to two complementary trends. Firstly, climate change is expected to increase the frequency and severity of climate-related events in some areas. Secondly, the economic impact may increase due to the growing number of people living in flood-prone areas, as well as increased economic activity in these areas (Bouwer, Crompton, Faust, Höppe, \& Pielke, 2007; Merz, Kreibich, Thieken, \& Schmidtke, 2004). Adaptation measures may lower the probability of flooding, reduce the potential damage; or transfer risks (Treby, Clark, \& Priest, 2006). Planning for climate resilient cities faces challenges in terms of energy and heat management. Holistic and strategic energy planning strives to reduce end-use energy demand and adopt urban energy supply systems for increasing shares of renewable energy, thereby strengthening urban energy resilience through lower long term costs of running urban energy systems. However, new infrastructure measures, either energy or water related, need to be implemented through urban planning and land use management. These measures involve a different use of space, which is often limited in urban environments. Hence, requirements for flood protection, water storage, green areas or different building strategies are competing, and priorities for the use of space have to be made.

Such models can identify the possible conflicts that result from competing claims on the same land for adaptation and other purposes. Dynamic insight in land development, competing claims and the requirements for adaptation can help to better inform spatial planning. At the same time it can help to analyse and visualize the possible options and their trade-offs on different urban functions. Although similar issues have been discussed for adaptation within the urban environment (e.g. Hamin \& Gurran, 2009) land use models have not frequently been used to illustrate the effects of adaptation in urban areas on urban functionalities. Haase, Haase, Kabisch, Kabisch, and Rink (2012) recently reviewed different urban modeling approaches. While each of these approaches has several advantages and disadvantages most models focus on the process of urbanization and its relation to urban form, distinguishing only broad classes of urban land use. Examples of such urban models include the MOLAND model (Petrov, Lavalle, \& Kasanko, 2009) and the SLEUTH model (Clarke, Gazulis, Dietzel, \& Goldstein, 2007). To properly address the ecosystem services provided by urban areas (Ernstson, Sörlin, \& Elmqvist, 2008) high spatial resolution and thematic detail is needed, often not available in current land use models (Borgström, Elmqvist, Angelstam, \& AlfsenNorodom, 2006; Lakes \& Kim, 2012). To support planning for adaptation in urban environments, improved methods for linking urban land use modeling and assessment of urban functions are required.

\section{Can policies limit urban sprawl?}

Contemporary urban spatial patterns, which derive from different land use strategies and policies, have been classified in three groups: the 'dispersed city', the 'compact city', and 'polycentric development' with the latter seen as being having high spatial values at multiple levels (Ostrom, 2010). As the alternative to the dispersed city and problems linked to sprawl, the compact city model (EC, 1990) suggests the intensive and innovative use of urban space, growth within city boundaries and a mixture of land uses. The real experience of European cities has shown some problems related to the compact city, such as congestion and overdevelopment with the absence of clear social benefits. Understanding the advantages and disadvantages of the dispersed and the compact city, the idea of polycentricity (decentralized concentration) underlies the European Spatial Development Perspective (EC,
1999), and implies the promotion of medium sized cities through their endogenous potential and the cooperation between urban areas as a means to achieve physically and functionally connected regions. The key objective is to combine economic growth and social and spatial cohesion. Specific sprawl problems in cities relate to differences in terms of economic and social opportunities as well as in terms of varying quality of environment in the individual areas of the city.

The Leipzig Charter on Sustainable European Cities (EUKN, 2007) stresses the importance of systematic and structured exchange of experience and knowledge in the field of sustainable urban development. The urban dimension of the current crisis and future challenges faced by European cities is highlighted in the need to promote a smarter, more sustainable and socially inclusive urban development (EC, 2010). In addition, the Toledo Declaration (Anon, 2010) proposes to develop a strategic commitment towards integrated urban regeneration in the existing fabrics and built environment with a sustainable, integrated growth model in new urban developments. This call for a traditional European city concept, striving for complexity, compactness, functional diversity, plurality and social integration, recognizes wide geographical and contextual diversity across European cities and towns, and rejects the application of 'one-size-fits-all' solutions in integrated urban regeneration plans and programmes, but points towards a more resilient urban destiny.

European contextual diversity deserves special attention with regard to sustainability and this makes the issues of resilience yet more challenging. While urban forms in North America follow, more or less, similar patterns, cultural diversity of European cities has resulted in a variety of urban forms that predetermine different types of sprawl. Since urban density is an essential factor of sprawl, respective processes differ in the Northern or North-western parts of the continent from those in France, most of Germany, Northern Italy or Austria, let alone urban densities and structures of Southern / Mediterranean Europe defined by substantially different cultural traditions (Leontidou, 1990). Another factor of critical importance with respect to sprawl is due to recent historical development, particularly the period of socialism that the countries in Eastern and South-eastern Europe went through during the second half of the 20th Century. Bertaud (2004) found that the radial density profile of cities in the former socialist countries had not changed radically from that of Western European cities. However, peripheral urban structures such as estates of prefabricated housing (the 'socialist suburbs') and hypertrophic industrial zones had altered the urban fringe dramatically. For this reason the processes of urban expansion follow patterns in South-eastern Europe varying from those in the Czech Republic, Slovakia, Poland and the Baltic states. Though sprawl had already been observed in the former socialist countries by many researchers (Hirt, 2007; Krisjane \& Berzins, 2009; Novák \& Sýkora, 2007; Tammaru, Kulu, \& Kask, 2004) planners in this part of the continent still underestimated the issue and the associated threats to sustainability. Therefore, comparative studies on the forms of urban expansion in different European longitudes and latitudes are urgently needed in order to identify possible responses of planning relevant to the specific national conditions.

\section{Can we move to short-circuit economies?}

Recognizing that economic and social legislation emerge slowly or can have conflicting effects creates challenges in relation to insufficient regulation of the transformations that irreversibly dissipate the land, producing a serious limitation to the welfare, the socio-economic development and the opportunities to be granted to future generations. The understanding of the effects of land use requires a sharing of skills: research relating to various disci- 
plines, such as urban ecology, geology, soil chemistry, geography and agronomy can help to provide a framework of full consciousness of the impacts of land use changes on the spheres of environment and local development. There is therefore a need for defining municipal accounting tools for land use, and the availability of non-urbanized and under-used areas. A promising solution may be seen in Product Service Systems (PSS) or the 'Green Servicing' approach. This is an emerging concept and is a business model devised and developed in academe and aimed at providing sustainability of both consumption and production (Cook, Bhamra, \& Lemon, 2006). Defined by Van Halen et al. as "a marketable set of products and services capable of jointly fulfilling a user's needs" (2005, p. 210), the initial move to PSS is largely motivated by the need on the part of traditionally oriented manufacturing firms to cope with changing market forces and the recognition that services in combination with products could provide higher profits than products alone (Sawhney, Balasubramanian, \& Krishnan, 2003). While there are some working examples - such as community car or bicycle sharing schemes - PSS activity is very poorly captured by economic statistics (USEPA, 2009), thus emerging economic tools and innovation opportunities have now a vital role in resilience planning, as well as offering an opportunity to embed resilience in communities.

\section{Conclusions}

Urban communities are, to some extent, becoming increasingly involved in decisions relating to planning and development, especially in environmentally-related issues (Curry, 2001). Deliberative, iterative mechanisms have been increasingly promoted as efficient in securing consensus in planning and this has been applied in collaborative planning theory (Healey, 1997; Innes \& Booher, 2004) and this has proven useful in generating successful approaches to management of rural landscape elements (Porter \& Salvesen, 1995; Raik \& Wilson, 2006; Sabatier et al., 2005). Early concern that this new direction may yield projects and initiatives that are low quality, short-term or non-sustainable have not been proven as a rule, and there is some evidence to suggest that stakeholder participation can improve on plans for new initiatives with the more intensive consultation of stakeholders yielding decisions of higher quality (Beierle, 2000; Beierle, 2002).

Social-ecological theory holds that both social and natural systems are vulnerable to sudden change but also contain a resilience to catastrophic change (Adger, 2000, 2006) and there is a growing literature of the implication to human health and well-being of diminishing ecological resilience (MA, 2005) and ecosystem services (Fisher \& Kerry Turner, 2008). Collaboration and participation in sustainability actions require knowledge of the various actors and an insight into their motivations and abilities (Primmer \& Kyllonen, 2006; Vlek \& Steg, 2007; Wu \& Hobbs, 2002). It is recognised that quality of life and land use are mutually interrelated (MA, 2005) and that urban planning ought to take this as a starting point if sustainability targets are to be achieved. In the past, greenway planning has been popularized as a mechanism for integrating the needs of biodiversity and social requirements (Ahern, 1995), but now there is a growing recognition of the interdependence of social and ecological systems in urban areas, mainly within resilience theory (Adger, 2000). This has resulted in calls for creative transitioning approaches to design and planning in urban areas in order to best meet multi-functional demands of ecosystem services, social requirements and biodiversity (Pickett \& Cadenasso, 2008). The questions discussed in this paper should be viewed as fundamental research topics, which act as 'signpost' opportunities for urban planners and practitioners to devise novel yet practical mechanisms for transitioning towards a more resilient city. Solutions that emerge from researching these questions may only become part of mainstream urban spatial development and policy with a considerable level of integration and synergistic approaches; a structured and multi-faceted transition strategy.

While it may be possible to develop practical solutions and guidelines, the process of transition may be much more problematic and may not suit policy time scales. Considerable differences and conflicting approaches may arise. For example, designing for resilience may present difficulties for socio-economic endeavours and market forces, as well as conflict with European trade policies and other subsidiarity issues; G-ICT data may not fully reflect ground level realities and thus may not represent the full range of stakeholder perceptions that are necessary for the collaborative processes; sustaining economic growth, even 'clean tech' endeavours, may conflict with urban neighbourhood regeneration and social cohesion; and so on. This may make the target of synergistic integration an over-idealized aim rather that a strategically appropriate and attainable policy. It simultaneously holds out, however, the possibility for new opportunities and innovations arising from such challenges. A panacea solution to these complex questions may not be specific enough to tackle the differing problems of each urban area alone. Transition strategies will therefore rely on combinations of solutions to the research questions discussed earlier, specifically tailored for the challenges of each city and relying on continual testing, demonstration and re-designing as time progresses. New challenges will emerge as older ones fade, as is common in all aspects of resilience planning, and the integration of these new challenges will no doubt require further research. Nonetheless, a transition strategy will permit the results to be measured and graded, thus permitting urban communities to view their progress and reinforce their efforts.

While resilience planning often takes a dichotomous standpoint the process of transition has, at its core, the aim of shifting paradigms towards a new vision of sustainable development where resilience implies normalizing environmentally sustainable practices. This is more closely aligned with the original drive towards sustainability seen in the Bruntland Report (WCED, 1987), and thus we return to seeking a more profound understanding of how sustainability will work in practice in the complexity of our cities. The questions discussed here are, we believe, key 'ingredients' in a potentially successful transition strategy, but the final 'recipe' will be rather more complex and will require many other contributions. Few would believe there is any standardized strategy, but rather transitioning will involve an unending adaptive process where learning-by-doing takes a pivotal role, and planning and practice professionals see community engagement as a truly collaborative process.

\section{Acknowledgements}

The authors acknowledge the financial support by the European Union FP7-ENV.2011.2.1.5-1 (TURAS Project) Grant Agreement No. 282834. The authors would also like to acknowledge the assistance if the following people in the preparation of this paper: Aoife Corcoran, Steven Deman, Louise Dunne, Mairin O'Cuireann, Patrick van den Abeele. In addition, we would like to express our sincere thanks to the editor for his creative comments and support.

\section{References}

Adger, W. N. (2000). Social and ecological resilience: Are they related? Progress in Human Geography, 24(3), 347-364.

Adger, W. N. (2006). Vulnerability Global Environmental Change, 16(3), 268-281. Adger, W. N., Brown, K., Nelson, D. R., Berkes, F., Eakin, H., Folke, C., Galvin, K. Gunderson, L., Goulden, M., O’Brien, K., Ruitenbeek, J., \& Tompkins, E. L. (2011). Resilience implications of policy responses to climate change. Wiley Interdisciplinary Reviews: Climate Change, 2(5), 757-766.

Ahern, J. (1995). Greenways as a planning strategy. Landscape and Urban Planning, 33, 131-155. 
Ahern, J. (2011). From fail-safe to safe-to-fail: Sustainability and resilience in the new urban world. Landscape and Urban Planning, 100(4), 341-343.

Alberti, M., \& Marzluff, J. M. (2004). Ecological resilience in urban ecosystems: Linking urban patterns to human and ecological functions. Urban Ecosystems, 7(3), 241-265.

Alberti, M., Marzluff, J. M., Shulenberger, E., Gordon, B., Ryan, C., \& Zumbrunnen, C. (2003). Integrating humans into ecology: Opportunities and challenges for studying urban ecosystems. Bioscience, 53(12), 1169-1179.

Allenby, B., \& Fink, J. (2005). Toward inherently secure and resilient societies. Science, 309, 1034-1036.

Anon (2010). Reference framework for European sustainable cities - The toledo declaration. <http://www.rfsustainablecities.eu/rubrique.php3?id_rubrique= 138> Accessed March, 2013.

Antrobus, D. (2011). Smart green cities: From modernization to resilience? Urban Research and Practice, 4(2), 207-214.

Antrop, M. (2004). Landscape change and the urbanization process in Europe Landscape and Urban Planning, 67(1-4), 9-26.

Beierle, T. C. (2000). The quality of stakeholder-based decisions: Lessons from the case study record. Discussion Paper 00-56. Washington: Resources for the Future.

Beierle, T. C. (2002). The quality of stakeholder-based decisions. Risk Analysis, 22(4), 739-749.

Bell, S., Montarzino, A., \& Travlou, P. (2007). Mapping research priorities for green and public urban space in the UK. Urban Forestry and Urban Greening, 6(2), 103-115.

Berkel, D., \& Verburg, P. (2012). Combining exploratory scenarios and participatory backcasting: Using an agent-based model in participatory policy design for a multi-functional landscape. Landscape Ecology, 27(5), 641-658.

Berkes, F., \& Turner, N. J. (2006). Knowledge, learning and the evolution of conservation practice for social-ecological system resilience. Human Ecology, 34(4), 479-494.

Bertaud, A. (2004). The spatial structure of central and eastern European cities: More European than socialist'. In Nedovic-Budic, Z., and Tsenkova, S. (Eds.) Winds of societal change: Remaking post-communist cities. International symposium on post-communist cities the Russian and East European Center (REEC). University of Illinois at Urbana-Champaign, June 17-19, 2004.

Borgström, S. T., Elmqvist, T., Angelstam, P., \& Alfsen-Norodom, C. (2006). Scale mismatches in management of urban landscapes. Ecology and Society, 11(2), 16.

Bouwer, L. M., Crompton, R. P., Faust, E., Höppe, P., \& Pielke, R. A. Jr., (2007) Confronting disaster losses. Science, 318(5851), 753.

Buccella, A., Cechich, A., \& Fillottrani, P. (2009). Ontology-driven geographic information integration: A survey of current approaches. Computers and Geosciences, 35(4), 710-723.

Budhathoki, N., Bruce, B., \& Nedovic-Budic, Z. (2008). Reconceptualizing the role of the user of spatial data infrastructure. GeoJournal, 72(3), 149-160.

Budhathoki, N. R., Nedovic-Budic, Z., \& Bruce, B. (2010). An interdisciplinary frame for understanding volunteered geographic information. Geomatica, 64(1), $11-26$.

Burgess, J., Clark, J., \& Harrison, C. M. (2000). Knowledges in action: An actor network analysis of a wetland agri-environment scheme. Ecological Economics, 35(1) 119-132.

Cameron, R. W. F., Blanuša, T., Taylor, J. E., Salisbury, A., Halstead, A. J., Henricot, B., \& Thompson, K. (2012). The domestic garden - Its contribution to urban green infrastructure. Urban Forestry and Urban Greening, 11(2), 129-137.

Clarke, K. C., Gazulis, N., Dietzel, C. \& Goldstein, N. C. (2007). A decade of SLEUTHing: Lessons learned from applications of a cellular automaton land use change model. Classics in IJGIS: Twenty years of the International Journal of Geographica Information Science and Systems (pp. 413-427).

Colding, J. (2007). Ecological land-use complementation for building resilience in urban ecosystems. Landscape and Urban Planning, 81(1-2), 46-55.

Colding, J., \& Barthel, S. (2013). The potential of 'Urban Green Commons' in the resilience building of cities. Ecological Economics, 86, 156-166.

Collier, M. J., \& Scott, M. (2008). Industrially harvested peatlands and after-use potential: Understanding local stakeholder narratives and landscape preferences. Landscape Research, 33(4), 439-460.

Collier, M. J., \& Scott, M. (2009). Conflicting rationalities, knowledge and values in scarred landscapes. Journal of Rural Studies, 25, 267-277.

Connop, S., Gedge, D., Kadas, G., Potter, R. \& Newport, D. (2009). Barking riverside green roof experiment. Phase 1: Report produced for knowledge transfer partners. <http://www.uel.ac.uk/erg/documents/Greenroof_expt_leaflet.pdf> Accessed March, 2013

Connop, S., Lindsay, R., Freeman, J., \& Kadas, G. (2011). Barking riverside: Office landscaping for biodiversity. Essex Naturalist (N.S.), 28, 49-67.

Cook, M. B., Bhamra, T. A., \& Lemon, M. (2006). The transfer and application of product service systems: From academia to UK manufacturing firms. Journal of Cleaner Production, 14(17), 1455-1465.

Cook, E., Hall, S., \& Larson, K. (2012). Residential landscapes as social-ecological systems: A synthesis of multi-scalar interactions between people and their home environment. Urban Ecosystems, 15(1), 19-52.

Coutinho-Rodrigues, J., Simão, A., \& Antunes, C. H. (2011). A GIS-based multicriteria spatial decision support system for planning urban infrastructures. Decision Support Systems, 51(3), 720-726.

Curry, N. (2001). Community participation and rural policy: Representativeness in the development of Millennium Greens. Journal of Environmental Planning and Management, 44(4), 561-567.
Davoudi, S. (2012). Resilience: A bridging concept or a dead end? Planning Theory and Practice, 13(2), 299-307.

de Vries, S., Verheij, R., Groenewegen, P., \& Spreeuwenberg, P. (2003). Natural environments-healthy environments? An exploratory analysis of the relationship between greenspace and health. Environment and Planning A 35(10), 1717-1732.

DEFRA (Department for Environment Food and Rural Affairs) (2011). The natural choice: Securing the value of nature. London: The Stationary Office.

Dunnett, N., \& Kingsbury, N. (2008). Planting green roofs and living walls. Portland: Timber Press.

EC (European Commission) (1990). Green paper: On the urban environment. Luxembourg: European Commission.

EC (European Commission) (1999). ESDP - European spatial development perspective: towards balanced and sustainable development of the territory of the European union. Luxembourg: Official Journal of the European Communities.

EC (European Commission) (2007). Directive 2007/2/EC of the European parliament and of the council of 14 March 2007 establishing an Infrastructure for spatial information in the European community (INSPIRE)'. Luxembourg: Official Journal of the European Communities.

EC (European Commission) (2010). Europe 2020. <http://ec.europa.eu/europe2020/ index_en.htm> Accessed March, 2013.

Ernstson, H., Sörlin, S., \& Elmqvist, T. (2008). Social movements and ecosystem services - The role of social network structure in protecting and managing urban green areas in Stockholm. Ecology and Society, 13(2), 39.

Ernstson, H., van der Leeuw, S. E., Redman, C. L., Meffert, D. J., Davis, G., Alfsen, C., \& Elmqvist, T. (2010). Urban transitions: On urban resilience and humandominated ecosystems. AMBIO: A Journal of the Human Environment, 39(8), 531-545.

EUKN (European Union Knowledge Network) (2007). The leipzig charter on sustainable European cities. <http://ec.europa.eu/regional_policy/archive/ themes/urban/leipzig_charter.pdf> Accessed March, 2013.

Fisher, B., \& Kerry Turner, R. (2008). Ecosystem services: Classification for valuation. Biological Conservation, 141(5), 1167-1169.

Folke, C., Hahn, T., Olsson, P., \& Norberg, J. (2005). Adaptive governance of socialecological systems. Annual Review of Environment and Resources, 30(1), 441-473.

Folke, C., Holling, C. S., \& Perrings, C. (1996). Biological diversity, ecosystems, and the human scale. Ecological Applications, 6(4), 1018-1024.

Förster, A. \& Thierstein, A. (2012). Enhancing the effectiveness of spatial planning processes: The systemic interplay of analysis, visualisation and communication. In AESOP 2012, Ankara, Turkey, July 11th - 15th.

Fry, G. L. A. (2001). Multifunctional landscapes: Towards transdisciplinary research. Landscape and Urban Planning, 57, 159-168.

Gidley, J. M., Fien, J., Smith, J.-A., Thomsen, D. C., \& Smith, T. F. (2009). Participatory futures methods: Towards adaptability and resilience in climate-vulnerable communities. Environmental Policy and Governance, 19(6), 427-440

Goddard, M. A., Dougill, A. J., \& Benton, T. G. (2010). Scaling up from gardens: Biodiversity conservation in urban environments. Trends in Ecology and Evolution, 25(2), 90-98.

Gómez-Baggethun, E., \& Barton, D. N. (2013). Classifying and valuing ecosystem services for urban planning. Ecological Economics, 83, 235-245.

Groenewegen, P., van den Berg, A., de Vries, S., \& Verheij, R. (2006). Vitamin G: Effects of green space on health, well-being, and social safety. BMC Public Health, 6(1), 149.

Guitart, D., Pickering, C., \& Byrne, J. (2012). Past results and future directions in urban community gardens research. Urban Forestry and Urban Greening, 11(4), 364-373.

Haase, D., Haase, A., Kabisch, N., Kabisch, S., \& Rink, D. (2012). Actors and factors in land-use simulation: The challenge of urban shrinkage. Environmental Modelling and Software, 35, 92-103.

Hakimpour, F. (2003). Using ontologies to resolve semantic heterogeneity for integrating spatial database schemata.

Haklay, M. (Ed.). (2010). Interacting with geospatial technologies. Chichester: John Wiley and Sons.

Hamin, E. M., \& Gurran, N. (2009). Urban form and climate change: Balancing adaptation and mitigation in the US and Australia. Habitat International, 33(3), 238-245.

Healey, P. (1997). Collaborative planning, shaping places in fragmented societies. London: Macmillan Press.

Hirt, S. (2007). Suburbanizing Sofia: Characteristics of post-socialist peri-urban change. Urban Geography, 28(8), 755-780.

Holling, C. S. (1973). Resilience and stability of ecological systems. Annual Review of Ecology and Systematics, 4, 1-23.

Hopkins, L. D., Kaza, N., \& Pallathucheril, V. G. (2005). Representing urban development plans and regulations as data: A planning data model. Environment and Planning B: Planning and Design, 32(4), 597-615.

Hostetler, M., Allen, W., \& Meurk, C. (2011). Conserving urban biodiversity? Creating green infrastructure is only the first step. Landscape and Urban Planning, 100(4), 369-371.

Huang, S.-C. L. (2010). The impact of public participation on the effectiveness of, and users' attachment to, urban neighbourhood parks. Landscape Research, 35(5), 551-562.

Hubacek, K., \& Kronenberg, J. (2013). Synthesizing different perspectives on the value of urban ecosystem services. Landscape and Urban Planning, 109(1), 1-6. 
Hunter, M. C. R., \& Brown, D. G. (2012). Spatial contagion: Gardening along the street in residential neighborhoods. Landscape and Urban Planning, 105(4), 407-416.

Innes, J., \& Booher, D. (2004). Reframing public participation: Strategies for the 21st century. Planning Theory and Practice, 5(4), 419-436.

Kadas, G. (2006). Rare invertebrates colonizing green roofs in London. Urban Habitats, 4(1), 66-86.

Kaplan, R., \& Kaplan, S. (1983). The experience of nature: A psychological perspective. Cambridge: Cambridge University Press.

Kennedy, C., Pincetl, S., \& Bunje, P. (2011). The study of urban metabolism and its applications to urban planning and design. Environmental Pollution, 159(8-9), 1965-1973.

Krisjane, Z., \& Berzins, M. (2009). Commuting and the deconcentration of the postsocialist urban population: The case of the Riga agglomeration. Folia Geographica, 14, 56-74.

Lacasta, J., Nogueras-Iso, J., Béjar, R., Muro-Medrano, P. R., \& Zarazaga-Soria, F. J. (2007). A Web Ontology Service to facilitate interoperability within a Spatial Data Infrastructure: Applicability to discovery. Data and Knowledge Engineering, 63(3), 947-971.

Lakes, T., \& Kim, H.-O. (2012). The urban environmental indicator "Biotope Area Ratio" - An enhanced approach to assess and manage the urban ecosystem services using high resolution remote-sensing. Ecological Indicators, 13(1), 93-103.

Lawrence, R. J. (2004). Housing and health: from interdisciplinary principles to transdisciplinary research and practice. Futures, 36(4), 487-502.

Lee, A. C. K., \& Maheswaran, R. (2010). The health benefits of urban green spaces: A review of the evidence. Journal of Public Health, 33(2), 212-222.

Leontidou, L. (1990). The Mediterranean City in Transition: Social change and urban, development. Cambridge University Press.

Ling, C., Handley, J., \& Rodwell, J. (2007). Restructuring the post-industrial landscape: A multifunctional approach. Landscape Research, 32(3), 285309.

Longley, P., Goodchold, M., Maguire, D., \& Rhind, D. W. (Eds.). (2010). Geographic information systems and science (3rd ed. Chichester: John Wiley and Sons.

Lüthi, C., McConville, J., \& Kvarnström, E. (2009). Community-based approaches for addressing the urban sanitation challenges. International Journal of Urban Sustainable Development, 1(1), 49-63.

MA (Millennium Ecosystem Assessment) (2005). Millennium ecosystem assessment Ecosystems and human well being: Synthesis report. Washington: Island Press.

Maas, J., Verheij, R. A., Groenewegen, P. P., de Vries, S., \& Spreeuwenberg, P. (2006). Green space, urbanity, and health: How strong is the relation? Journal of Epidemiology and Community Health, 60(7), 587-592.

Marafa, L. M. (2002). Socio-ecological impact and risk assessments in the urban environment: A multidisciplinary concept from Hong Kong. The Environmentalist, 22(4), 377-385.

Masser, I. (2005). GIS worlds - Creating spatial data infrastructures. ESRI: ESRI Press.

Merz, B., Kreibich, H., Thieken, A., \& Schmidtke, R. (2004). Estimation uncertainty of direct monetary flood damage to buildings. Natural Hazards and Earth System Science, 4(1), 153-163.

Naveh, Z. (2000). What is holistic landscape ecology? A conceptual introduction. Landscape and Urban Planning, 50, 7-26.

Nedovic-Budic, Z. (2010). Local government applications: Toward E-Governance. In J. Bossler (Ed.), Manual of Geospatial Science and Technology (2nd ed. London: Taylor \& Francis.

Nedovic-Budic, Z., Feeney, M.-E. F., Rajabifard, A., \& Williamson, I. (2004). Are SDIs serving the needs of local planning? Case study of Victoria, Australia and Illinois, USA. Computers, Environment and Urban Systems, 28(4), 329-351.

Nedović-Budić, Z., Knaap, G.-J., Budhathoki, N. R., \& Cavrifá, B. (2009). NSDI building blocks: Regional GIS in the United States. Journal of the Urban and Regional Information Systems Association, 21(2), 5-23.

Novák, J., \& Sýkora, L. (2007). A city in motion: Time-space activity and mobility patterns of suburban inhabitants and the structuration of the spatial organization of the prague metropolitan area. Geografiska Annaler: Series B, Human Geography, 89(2), 147-168.

Nyerges, T., \& Jankowski, P. (2009). Regional and urban GIS: A decision support approach. Guilford Press.

Ostrom, E. (2010). Polycentric systems for coping with collective action and global environmental change. Global Environmental Change, 20(4), 550-557.

Palang, H., Alumae, H., \& Mander, U. (2000). Holistic aspects in landscape development: A scenario approach. Landscape and Urban Planning, 50(1-3), 85-94.

Petrov, L. O., Lavalle, C., \& Kasanko, M. (2009). Urban land use scenarios for a tourist region in Europe: Applying the MOLAND model to Algarve, Portugal. Landscape and Urban Planning, 92(1), 10-23.

Pickett, S. T. A., \& Cadenasso, M. L. (2008). Linking ecological and built components of urban mosaics: An open cycle of ecological design. Journal of Ecology, 96(1), $8-12$.

Pickett, S. T. A., Cadenasso, M. L., Grove, J. M., Nilon, C. H., Pouyat, R. V., Zipperer, W. C., \& Costanza, R. (2001). Urban ecological systems: Linking terrestrial ecological, physical, and socioeconomic components of metropolitan areas. Annual Review of Ecology and Systematics, 32, 99-122.

Porter, L., \& Davoudi, S. (2012). The politics of resilience for planning: A cautionary note. Planning Theory and Practice, 13(2), 329-333.

Porter, D. R., \& Salvesen, D. A. (Eds.). (1995). Collaborative planning for wetlands and wildlife: Issues and examples. Washington: Island Press.
Primmer, E., \& Kyllonen, S. (2006). Goals for public participation implied by sustainable development, and the preparatory process of the Finnish Nationa Forest Programme. Forest Policy and Economics, 8(8), 838-853.

Raik, D. B., \& Wilson, A. L. (2006). Planning in collaborative wildlife management: A critical perspective. Journal of Environmental Planning and Management, 49(3), 321-336.

Sabatier, P. A., Focht, W., Lubell, M., Trachtenberg, Z., Vedlitz, A., \& Marty, M. (2005) Collaborative approaches to watershed management. In P. A. Sabatier, W. Focht, M. Lubell, Z. Trachtenberg, A. Vedlitz, \& M. Martyeds (Eds.), Swimming upstream: Collaborative approaches to watershed management. Cambridge: MIT Press.

Salvemini, M. F. V. \& Iannucci, C. (2011). Plan4All Project - Interoperability for spatial planning. Plan4all consortium.

Sawhney, M., Balasubramanian, S., \& Krishnan, V. V. (2003). Creating growth with services. MIT Sloan Management Review, 45(2), 34-44.

SCBD (Secretariat of the Convention on Biological Diversity) (2012). Cities and biodiversity outlook. Montreal: Secretariat of the Convention on Biological Diversity.

Selman, P. (2004). Community participation in the planning and management of cultural landscapes. Journal of Environmental Planning and Management, 47(3) 365-395.

Sheppard, S. R. J. (2005). Landscape visualisation and climate change: The potential for influencing perceptions and behaviour. Environmental Science and Policy, $8(6), 637-654$.

Silva, C. N. (2010). Handbook of research on E-planning: ICTs for urban development and monitoring. New York: Information Science Reference.

Simmons, M., Gardiner, B., Windhager, S., \& Tinsley, J. (2008). Green roofs are not created equal: The hydrologic and thermal performance of six different extensive green roofs and reflective and non-reflective roofs in a sub-tropical climate. Urban Ecosystems, 11(4), 339-348.

Slee, B. (2007). Social indicators of multifunctional rural land use: The case of forestry in the UK. Agriculture, Ecosystems and Environment, 120(1), 31-40.

Sui, D., \& Goodchild, M. (2011). The convergence of GIS and social media: Challenges for GIScience. International Journal of Geographical Information Science, 25(11), 1737-1748.

Takano, T., Nakamura, K., \& Watanabe, M. (2003). Urban residential environments and senior citizens' longevity in megacity areas: The importance of walkable green space. Journal of Epidemiology and Community Health, 56, 913-918.

Tammaru, T., Kulu, H., \& Kask, I. (2004). Urbanization, suburbanization, and counterurbanization in Estonia. Eurasian Geography and Economics, 45(3), 212-229.

Treby, E. J., Clark, M. J., \& Priest, S. J. (2006). Confronting flood risk: Implications for insurance and risk transfer. Journal of Environmental Management, 81(4) 351-359.

Twiss, J., Dickinson, J., Duma, S., Kleinman, T., Paulsen, H., \& Rilveria, L. (2003) Community gardens: Lessons learned from California healthy cities and communities. American Journal of Public Health, 93(9), 1435-1438.

Tzoulas, K., Korpela, K., Venn, S., Yli-Pelkonen, V., Kazmierczak, A., Niemela, J., \& James, P. (2007). Promoting ecosystem and human health in urban areas using green infrastructure: A literature review. Landscape and Urban Planning, 81(3), 167-178.

Ulrich, R. S. (1984). View through a window may influence recovery from surgery. Science, 224(4647), 420-421.

UNDP (United Nations Development Programme) (1997). Governance for sustainable human development. A UNDP policy document. New York: United Nations Development Programme.

USEPA (United States Environmental Protection Agency) (2009). Green servicizing for a more sustainable US economy: Key concepts, tools and analyses to inform policy engagement. Washington: US Environmental Protection Agency.

van de Meene, S. J., Brown, R. R., \& Farrelly, M. A. (2011). Towards understanding governance for sustainable urban water management. Global Environmental Change, 21(3), 1117-1127.

Van Halen, C., Vezzoli, C., \& Wimmer, R. (2005). Methodology for product service system innovation: How to develop clean, clever and competitive strategies in companies. Assen: Uitgeverij Van Gorcum.

Vigar, G., \& Healey, P. (2002). Developing environmentally respectful policy programmes: Five key principles. Journal of Environmental Planning and Management, 45(4), 517-532.

Vlek, C., \& Steg, L. (2007). Human behavior and environmental sustainability: Problems, driving forces and research topics. Journal of Social Issues, 63(1) $1-19$.

Vos, W., \& Meekes, H. (1999). Trends in European cultural landscape development: Perspectives for a sustainable future. Landscape and Urban Planning, 46(1-3), $3-14$.

Wang, H., Song, Y., Hamilton, A., \& Curwell, S. (2007). Urban information integration for advanced e-planning in Europe. Government Information Quarterly, 24(4), 736-754.

WCED (World Commission on Environment and Development) (1987). Our common future. Oxford: Oxford University Press.

Wilkinson, C. (2012a). Social-ecological resilience: Insights and issues for planning theory. Planning Theory, 11(2), 148-169.

Wilkinson, C. (2012b). Urban resilience: What does it mean in planning practice? Planning Theory and Practice, 13(2), 319-324.

Wu, J., \& Hobbs, R. (2002). Key issues and research priorities in landscape ecology: An idiosyncratic synthesis. Landscape Ecology, 17(4), 355-365. 